\title{
A Study on Secondary School Organizational Climate and Work Values of Secondary School Heads
}

\author{
Vedavathi.B \\ Research scholar in education, Department of studies in education, Mysore University, Karnataka. India
}

\begin{abstract}
A study on work values of secondary school Heads and School organizational climate has been dealt with in this paper. The sample considered 220 secondary school heads of South Canara District at Karnataka State in India by stratified random sampling technique including government, private aided, private un-aided and minority schools. The Data was collected by using Work Values scale and SOCDQ. The study found that there is no significant difference between the work values of secondary school Heads working in different School climates and found significant difference in school climates with different types of schools
\end{abstract}

Keywords: classic schools, eminent, secondary school Heads, school climate, work values

\section{Introduction}

The National Curriculum Framework, 2005 echoed the vision of education where values are inherent in every aspect of schooling. The framework articulates the need to reaffirm our commitment to the concept of equality amidst diversity, mutual interdependence of humans to promote values that foster peace, humaneness and tolerance in a multi cultural society (p.2). Values heartily influence personal and organizational decisionmaking. The values of leaders primarily shape the cultures of their organizations through modeling important values and ultimately permeate the organizations they lead. The activities of the school are determined by what the Head teacher does. He/she influences everyone else's behavior: his /her values are contagious, his/her good sense of ethics instills respect and trust in the system; he/she extends a powerful message about what is important, how people are to be treated and how the school should operate. O' Hanlon and Clifton (2004:2-3) hold that a positive school climate does not exist by chance rather the Head teacher's expectations, examples and values shape the climate of the school. Thus, it appears that the Head teacher's leadership pattern influence the school climate. In classic schools, the school community shares values, goals and work as a team. Teamwork can enhance quality management in schools as teams can utilize resources more efficiently and increase organizational effectiveness, improve the quality of educational programs and create better learning and working environments. Thus, successful teamwork is considered an indispensable ingredient in the process of building successful school climate. The democratic leadership style encourages school community to participate in the events of the school as a whole. The staff feels they are part of the school, and hence they take part in the leadership of the school. It is important to note that in modern societies work values are typically considered as salient, basic, and influential. the importance of the work role in many cultures make work values in to core values that take a basic position in the overall pattern of values. There is a general opinion in the literature that values do not influence people's activity directly, but rather indirectly, through attitudes and goals.

The position of the school head is evidently indispensable in consideration with the multiplicity of commitments and responsibilities he organizes, involving the staff teachers, students, parents, society and the stack holders. A clear understanding of employee work value structure helps employers and managers in developing effective human resource policies that meet employee's needs and achieve satisfactory work outcomes in areas that their employees value most and work values of individual who takes part in the organization influence greatly on organization climate. Blake and Mouton (1985) indicated that leaders who fully understand leadership theory and improve their ability to lead are able to reduce employee frustration and negative attitudes in the work environment

\section{Organizational Climate}

In the information economy, most successful Organizations must be knowledge oriented values added enterprises, such as environment requires school to be true learning centers where students are engaged in challenging and interesting academic work or multy academic task. Teachers and administrators are collaboratively involved in learning about the most effective instructional strategies and technologies. Operationally organizational climate of a school refers to the administration, teachers, students, location, building and their influence on each other. According to Halpin and Croft (1963) organizational climate is a flow of behavior and feeling in a group, they state "personality is to the individual what organizational climate is to the organizations. Organizational climate refers to a set of organizational characteristics which can be created from the way an organization deals with its members. 


\subsection{School Climate}

School climate reflects the physical and psychological aspects of the school that are more susceptible to change and provide the preconditions necessary for teaching and learning to take place and also a significant factor in process about improving academic performance and school reform.

"Healthy School climate is one of the most important ingredients of a successful instructional program. The climate of the school attitudes of the teaching staff and support from the parents influence student achievement. As instructional leaders, principals can foster an understanding of the school vision, facilitate execution of the mission, and establish the school climate. Ubben and Hughes (1992) stated that principals could create a school climate that improves the productivity of both staff and students and that the leadership style of the principal can foster or restrict teacher effectiveness. Ultimately, values serve as the foundational essence of eminent leadership so that good human relationship can be established by being a role model so as to reform classic school model.

\subsection{Components of School Climate:}

Several aspects of school's physical, social and psychological environment compose its climate. i.e. School Administration, Appearance and physical plant, Faculty relations, Student's interactions, Learning environment, Students-Faculty members involvement, Attitudes and culture, School-community relations, socio-economic background, Support from the stake holders. In the "School Organizational Climate Descriptive Questionnaire" developed by Motilal Sharma (1978) considered the climates namely open climate, Autonomous climate. Familiar climate, controlled climate. Paternal climate and closed climate. A better achievement found in the case of familiar climate schools (Sharma, 1982).

\section{Work Values}

The work values mainly refer to the preparation for work, concept of the work and association with work related activity. i.e. the overall attitudes toward work. Work Values indicate something what one considers worthy of position in thought and action. Values standardize and guide human attitude, behavior and action in our day to daily life, are embedded in every word we select and speak, what we wear, ways in which values we interact, our perceptions and interpretation of other's reactions in, what we respond, how we convey and so on. Values that have some material return or outcome, such as payment, vacation, job security, permanent job, convenient hours of work, Comfortable and clean work conditions, achievement, opportunity for personal growth and contribution to society, advancement, chances of promotion, feedback concerning the work, job status, job interest to do work, meaningful work, use of ability and knowledge, work responsibility, independence in work company, influence in the organization, interpersonal relationships etc

Elizur (1996); analyzed the relationships between Work Values and Organizational Commitment based on a sample of adults in Israel. A group of 144 randomly chosen adults in Israel responded to a questionnaire which contained 24 Work Values previously identified by Elizur (1984). The strongest relationships were observed between cognitive Work Values and commitment, e.g. independence, job interest and use of abilities, relatively high correlation was also observed with payment. Work values are concerned with an individual's belief towards work performances and evaluative standards relating to work (Elizer 1995). Material or Instrumental values, Cognitive Values and affective values are the components of work values considered.

Research started in the work environment through the study of climate and culture and in the 1960s began to be applied to educational settings. Super's (1970) Work Values Inventory (WVI) was developed in the 1950s as a means of assessing "the various goals that motivate men to work" (Super,1970) Super envisioned Work Values as derived from needs and serving as the objectives or goals that one seeks to attain in satisfying those needs. Super posited that needs are cognitively expressed as values. Which are the goals that are attained through more than one type of activity or occupation; He defined interest as the more specific activities and objects through which values are expressed in meeting needs (Super, 1973). Super (1970) argued that it is more fruitful to examine values as the standards upon which we determine our interests than to examine the specific interests themselves.

\section{Need For The Study}

Literature review shows that: study on Work Values of secondary school heads and school organizational climate is not Adequate in India. There is a need for value based school climate with Multy task leadership is the necessity of present education system. Especially in south canara district (Karnataka state in India), an education hub exhibits outstanding student achievement in secondary education. This has motivated the researcher to investigate the relationship between the Work Values of Heads of secondary schools with different school climates. Researcher hopes that the findings of the study will be useful in the field of educational administration. Thus it is felt that there is a need for the present study. 


\section{Objectives of the Study}

To find the difference between Work Values of heads of secondary schools with different school climates and to find the difference between the secondary school climates in different types of school (government, private aided, private unaided and minority).

\section{Hypothesis;}

In pursuance of the objectives following Null Hypotheses were set up.

There is no significant difference between the work values of secondary school heads with different secondary school climates. There is no significant difference in school climates of different types of secondary schools.

\section{Design And Methodology of The Study}

Survey method is adopted to collect the data involving descriptive cum comparative research and it is taken up at South Canara district of Karnataka state in India. The data was collected by administering tool in six educational blocks of South Canara district. 3 types of high schools considered are, Government high schools (VIII-X) Run by the government of Karnataka, Private- Aided high schools (VIII-X) with financial aid provided by the government of Karnataka and Private- unaided high schools (VIII-X) without financial aid provided by the government of Karnataka.

\section{Tools and Data Collection}

In the present study "School Organizational Climate Descriptive Questionnaire" developed by Motilal Sharma (1978) would be used. This tool is an Indian adaptation of "Organizational Climate Descriptive Questionnaire" of Halpin and Croft .The scale consists of 64 Likert type items distributed over eight dimensions of organizational behaviors and type of school climate is a function of dimensions which are focusing on in schools.

Dimensions are grouped under two categories i.e Leader behavior characteristics and Group behavior characteristics consisting of, Disengagement Alienation, Esprit, Intimacy, Psychological Hindrance, Control, Production Emphasis and Humanized thrust. His behavior is viewed favorably by the teachers (Sharma, 1978). A profile of these dimensions in each school would determine the type of climate which is dominated in school.1.Open climate 2.Auotonomous climate, 3.Familiar climate 4.Controlled climate. 5. Paternal climate. 6. Closed climate. Work values Questionnaire by Elizur (1996); was adopted.

In order to collect the data by using the tools, Investigator approached secondary school heads personally, educational block wise with the permission of Department of Public Instruction South Canara District. Demographic data sheet was prepared by the researcher to collect the details of selected variables of secondary school heads.

\section{Findings}

The study found that, the work values (and components, cognitive component, material component, and affective component) of secondary school heads working in different school climates have no significant differences. School climates of different type of secondary schools exhibited significant difference between them. So work value is clearly independent variable and not affected by the school climates. Therefore the null Hypothesis in this regard is accepted.Table-1\& table-2. 2. Climates of different types of secondary schools concluded significant difference among them so the $2^{\text {nd }}$ Null hypothesis is rejected. Types of management considered are also likely to be more related to the work values of secondary school heads and school organizational climate.

\section{Conclusion}

The researcher made a practical and concerned effort systematically to arrive at the findings. At the secondary school level in the present study it is observed that the work values of the head have significant contribution towards his/her Instructional leadership so that the quality of school climate could be reformed to achieve the aims and objectives of education. From this study it is concluded that many factors of work values influence the leadership of secondary school heads and of course work values find special place in the field of educational system. The study found that secondary school heads perceive themselves as exhibiting work values at a high frequency. They must be given more opportunities to reform and expand the better school climates. It is difficult for a sophisticated environment of today's secondary education to be managed. It takes a team of dedicated; at the same time entire school community should be supportive. The final recommendation is to develop and effectively mentor continuously the secondary school heads as instructional leaders and to achieve the goals of school reform, work values take an enormous position, so, the effective Instructional leadership preparation must become a first concern of our Nation. 
The work values (components) of secondary school heads in different secondary school climates.

TABLE-1

Descriptives

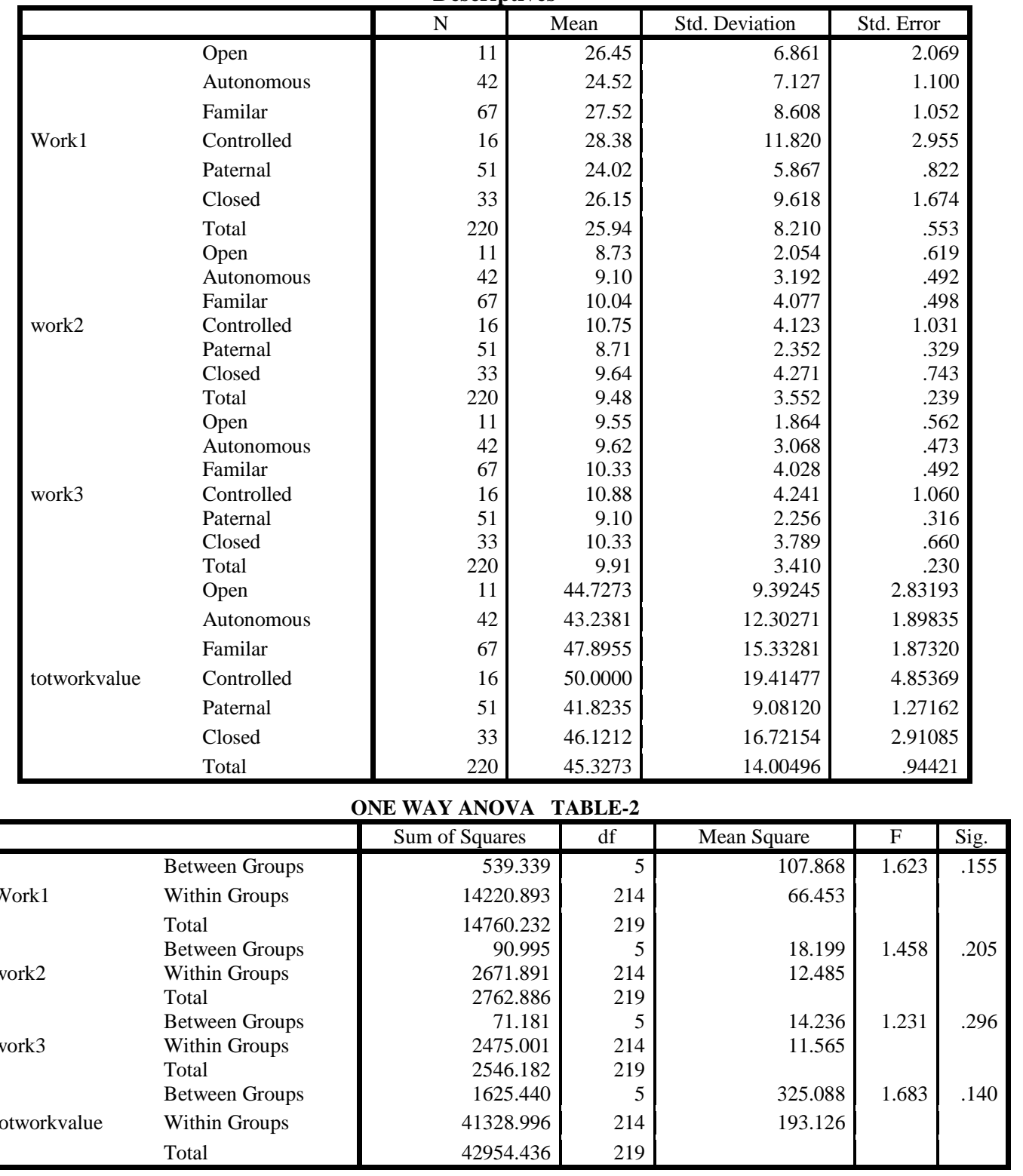

The School Climates of Different types of Secondary schools; Table-3

Crosstab

\begin{tabular}{|c|c|c|c|c|c|c|c|}
\hline & & & \multicolumn{4}{|c|}{ SCHOOLTYPE } & \multirow[t]{2}{*}{ Total } \\
\hline & & & Govt & Pvt aid & Pvt unaid & Minority & \\
\hline \multirow{12}{*}{ soc } & \multirow{2}{*}{ Open } & Count & 4 & 1 & 5 & 1 & 11 \\
\hline & & $\%$ within soc & $36.4 \%$ & $9.1 \%$ & $45.5 \%$ & $9.1 \%$ & $100.0 \%$ \\
\hline & \multirow{2}{*}{ Autonomous } & Count & 29 & 6 & 4 & 3 & 42 \\
\hline & & $\%$ within soc & $69.0 \%$ & $14.3 \%$ & $9.5 \%$ & $7.1 \%$ & $100.0 \%$ \\
\hline & \multirow{2}{*}{ Familar } & Count & 9 & 7 & 36 & 15 & 67 \\
\hline & & $\%$ within soc & $13.4 \%$ & $10.4 \%$ & $53.7 \%$ & $22.4 \%$ & $100.0 \%$ \\
\hline & \multirow{2}{*}{ Controlled } & Count & 7 & 4 & 4 & 1 & 16 \\
\hline & & $\%$ within soc & $43.8 \%$ & $25.0 \%$ & $25.0 \%$ & $6.2 \%$ & $100.0 \%$ \\
\hline & \multirow{2}{*}{ Paternal } & Count & 16 & 19 & 14 & 2 & 51 \\
\hline & & $\%$ within soc & $31.4 \%$ & $37.3 \%$ & $27.5 \%$ & $3.9 \%$ & $100.0 \%$ \\
\hline & \multirow{4}{*}{ Closed } & Count & 15 & 8 & 4 & 6 & 33 \\
\hline & & $\%$ within soc & $45.5 \%$ & $24.2 \%$ & $12.1 \%$ & $18.2 \%$ & $100.0 \%$ \\
\hline \multirow{2}{*}{ Total } & & Count & 80 & 45 & 67 & 28 & 220 \\
\hline & & $\%$ within soc & $36.4 \%$ & $20.5 \%$ & $30.5 \%$ & $12.7 \%$ & $100.0 \%$ \\
\hline
\end{tabular}


TABLE-4

Symmetric Measures

\begin{tabular}{|ll|r|r|}
\hline & & \multicolumn{1}{|c|}{ Value } & \multicolumn{1}{c|}{ Approx. Sig. } \\
\hline Nominal by Nominal & Cramer's V & .323 & $\mathbf{. 0 0 0}$ \\
\hline
\end{tabular}

\section{Journal Papers}

\section{References}

[1]. Meena Dorathi - Organizational climate and service Orientation in select schools.(The IUP Journal of Organizational behavior vol X No.2.20011)

[2]. Michael Henderson\&DougalThompson; How do values influence group development \&Organisational culture? -articl

[3]. Jan chell- Summary of a master's project: "Introducing principal's to the role of instructional leadership" SSTA Research Center report \#95-14; pages, \$14.Celidonio B Descallar. "Work Values and Satisfaction of secondary school teacher" Thesis presented to the faculty of the graduate school phillippine Chistian University.

[4]. Robert A-Roe, - Applied Psychology: An international Review 1999, 48(1), Values and work: Empirical Findings and Theoretical perspective- work and organization Research centre, Tilburg university. The Netherlands-peter Ester -IVA-Institute for social Research, Tilburg University, the Netherlands.

\section{Inventory}

[5]. Work value Inventory by Elizur (1984)

[6]. Super's Work value Inventory ((1970)

Books

[7]. The National Curriculum Framework, 2005

[8]. Halpin and Croft .A.W and Croft D.B (1963) The Organizational climate of the schools, Chicago;Mid-West Administrative center.

[9]. Sharma,M.L (1978). Technical hand book for School Organizational Climate Descriptive Questionnaire, Surat;South Gujar University

[10]. Sharma,M.L (1982) . Diagnosing school climate, Rajasthan International Consultants

[11]. Dr.Shefali R. Pandaya- School Effectiveness. Published S-B Nagia A.P.H Publishing Corporation 4435-36/7 Ansari road Darya GAnj new Delhi-110

Thesis

[12]. Faranak Joulideh(2008);“'Organizational commitment and work values of teachers and leadership behavior of heads of high schools in Banglore (INDIA) and SanandaJ (IRAN)- A comparative study"

[13]. Hamid Reza Razavi-"Instructional leadership Behaviors of secondary school principals (headmasters) Teacher efficacy and school organizational climate” A comparatiys study in mysore (india) and in Amol (iran). 